\title{
The Effects of Good Governance on the Socio Economic Development of local people
}

\author{
Sekou Maiga, Xu Feng Ju
}

\author{
Wuhan University of Technology (WHUT), Mafangshan ,West Campus ,Post Doctoral \\ Building,china.
}

Sekouma17@yahoo.com

\begin{abstract}
Key words : Good Governance; Lasting Peace; Social Stabilization;Good Collection of Taxes, Successful Decentralization.

Abstract.The analysis indicates a positive correlation between good governance, equitable justice and lasting peace, the Good governance put the citizens in a good disposition, citizens know their revenues is well managed. This provide them happiness, it appeases citizens, the equitable justice satisfies all citizens because it avoids the concept of superman or man above the law. The greatest obstacle to peace is injustice, Because if the citizens know they are all equal under the law, that will reinforces peace feeling, The significant increase of civil servants salary is very important because the public administration reflects the government, the government relies on the public servants staff for the implementation of government policy.
\end{abstract}

\section{Introduction}

\subsection{Definitions of good governance}

Good governance is an indeterminate term used in international development literature to describe how public institutions conduct public affairs and manage public resources. Governance is "the process of decision-making and the process by which decisions are implemented (or not implemented)". The term governance can apply to corporate, international, national, local governance or to the interactions between other sectors of society.

The concept of "good governance" often emerges as a model to compare ineffective economies or political bodies with viable economies and political bodies. The concept centers on the responsibility of governments and governing bodies to meet the needs of the masses as opposed to select groups in society.

\subsection{Characteristics of Good Governance}

\subsubsection{Participation}

All men and women should have a voice in decision-making, either directly or through legitimate intermediate institutions that represent their interests. Such broad participation is built on freedom of association and speech, as well as capacities to participate constructively.

\subsubsection{Rule of law}

Legal frameworks should be fair and enforced impartially, particularly the laws on human rights.

\subsubsection{Transparency}

Transparency is built on the free flow of information. Processes, institutions and information are directly accessible to those concerned with them, and enough information is provided to understand and monitor them.

\subsubsection{Responsiveness}

Institutions and processes try to serve all stakeholders. 


\subsubsection{Consensus orientation}

Good governance mediates differing interests to reach a broad consensus on what is in the best interests of the group and, where possible, on policies and procedures.

\subsubsection{Equity}

All men and women have opportunities to improve or maintain their well-being.

\subsubsection{Effectiveness and efficiency}

Processes and institutions produce results that meet needs while making the best use of resources.

\subsubsection{Accountability}

Decision-makers in government, the private sector and civil society organisations are accountable to the public, as well as to institutional stakeholders. This accountability differs depending on the organisations and whether the decision is internal or external to an organisation.

\section{Data}

\section{1 Data collection}

The data collected were provided by the National Statistics Institute (INSAT) and the General Directorate of local authorities (DGCT), The INSAT is responsible for data collection at the national level, the DGCT is responsible for the support of communities throughout the national territory, Daily accounting transactions are saved from all directorates using the TABOR public accounting software, that is, state accounting. The software is designed to track daily income and expenditure of all financial administrations. The data is updated on a daily basis.

We chose to collect data by this method because it is modern and its the simplicity, reliability and consistency are advantageous to us. This method is very reasonable because the data can be captured effectively between different structures involved in the chain of command. It has the advantage of taking account balances at the beginning of year, and then continues balancing the accounts with every subsequent transaction. It is for these reasons that when it comes to tax data collection we had preference for this type of method.

\subsection{Data Analysis}

The data was analyzed through the use of the econometric software EVIEWS. It allows us to employ the following model

$\mathrm{TY}_{\mathrm{t}}=\beta_{0}+\alpha_{1} \mathrm{TEX}_{\mathrm{t}}+\alpha_{2} \mathrm{TM} 2_{\mathrm{t}}+\alpha_{3} \mathrm{DN}_{\mathrm{t}}+\alpha_{4} \mathrm{SAVY}_{\mathrm{t}}+\theta$

The choice of the regression method (Haussmann statistic) we retain econometric panel data because of many advantage she present in the analysis of determinants of growth. It will pair methods used to time series and cuts. For more, the estimation of models of growth requires long data panel econometrics allows for. The choices of econometric of panel require certain number of choice, for precaution and verification. The cylinder panel because it offer a results more relevant than the panels non cylinder.

\subsection{Estimated econometric model}

The model to be estimate is borrowed from Amable and Guellec [7] and the linear test equation is given by: 
Lasting peace $=c+\beta_{1}$.décentralization $+\beta_{2}$.good governance $+\beta_{3}$ equitable justice $+\beta_{4}$. Substantial increase of civil servants salary $+\beta_{5}$ good perception of taxes, $+\beta_{6}$. The performance of public works contracts +et.

\section{Results and finding}

\subsection{Results}

The analysis indicates a positive correlation between good governance, equitable justice and lasting peace, the Good governance put the citizens in a good disposition, citizens know their revenues is well managed. This provide them happiness, it appeases citizens, the equitable justice satisfies all citizens because it avoids the concept of super man or man above the law. The greatest obstacle to peace is injustice, Because if the citizens know they are all equal under the law, that will reinforces peace feeling, The significant increase of civil servants salary is very important because the public administration reflects the government, the government relies on the public servants staff for the implementation of government policy. the public servants are the backbone of the public administration. if the public servants are put in good work conditions it will turn them away from corruption that plagues the administration of several countries, the increased purchasing power of civil servants will push them to work correctly in all fields: equitable justice, good tax collection, performance of public works contracts, good governance .

\subsection{Finding}

Finally all these concepts have a positive correlation with peace, their individual performance avoids crises, discontent, uprisings that may undermine peace, which can be an obstacle to peace. which can constitute a barrier to peace.

The War is a mix of negative elements such as; bad governance, a partial justice, bad performance of the public works contracts, corruption due to low wages of civil servants and finally poor perception of taxes.

Successful decentralization leads to a lasting peace within the population because citizens know they have their own destiny in hand through the choice of their leader and in the management of local resources

\section{References}

[1]Han, Z., 1999. Report on the work of Supreme People's Procuratorate of PRC. People's Daily 21 March.

[2] He, Z., 1995. A Political Cancer: A Study on the Corruption Problem of the Developing Countries. Central Compilation and Translation Press, Beijing.

[3]He, Z., 2000. Democratization under reforming China: progress, problems and prospects (English Version). In press.

[4]Hu, H., 1989. Three strategies of anti-corruption. Comparative Economic and Social System (3), 20.

[5]Li, P., 1999. Report on the work of government. China Daily 16 April.

[6]Liang, G., 1994. The Practical Encyclopaedia of Anti-corruption in China and Foreign Countries. XinHua Press, Beijing.

[7]Wang, H., 1990. Anti-corruption: China’s Experiment. San Huan Press, Hai Kou.

[8]Wei, J., 1993. Adopt to the new situation, anti-corruption in depth, serve for implementing comprehensively the fundamental lines of CPC. In: CCDI (Eds.), Fight Against Corruption Firmly,Fang Zheng, Beijing, p. 19.

[9]Wei, J., 1998. Fines not sources of income for units. China Daily 22 May. 
[10]White, G., 1996. Corruption and the transition from socialism in China. 